\title{
Koulutusta ja työkokemusta arvostetaan, mutta rahamääräiset tuotot laskevat
}

\begin{abstract}
$+y$
"Työuran aikana hankittu ammatillinen aikuiskoulutus on vaikuttanut eniten työpaikan sisäiseen liikkuvuuteen, jonka kanssa myös aikuiskoulutuksen palkkavaikutus vahvasti korreloi. Mutta ammatillisten siirtymien tukena, kuten työpaikan tai ammatin vaihdossa, aikuiskoulutuksen rooli on pysynyt vaatimattomana", kirjoittaa Erkki Laukkanen, joka väitteli vuonna 2010 koulutuksen ja työkokemuksen vaikutuksesta tulokehitykseen. Työsuhdeturva ja urakehitys ovat palkansaajille palkkaa tärkeämpiä arvoja.
\end{abstract}

INHIMILLISEN PÄÄOMAN teorian mukaan koulutus on investointi tuottavuuteen, josta työnantajan kannattaa maksaa. Koulutuksen taloustieteessä huomio on sittemmin kiinnittynyt kahteen inhimillisen pääoman muotoon, ammatilliseen peruskoulutukseen ja työkokemukseen. Useimmissa Suomeen verrannollisissa maissa yksi lisävuosi muodollista, tutkintoperusteista koulutusta nostaa palkkaa 7-9 prosenttia. Vastaavasti yksi työkokemusvuosi nostaa palkkaa noin prosentin. (Asplund \& Pereira 1999; Asplund 2000; Psacharopoulos \& Patrinos 2002).

Aikuiskoulutuksen palkkavaikutusta käsittelevässä väitöskirjassani (Laukkanen 2010) päädyin siihen, että myös ammatillisella aikuiskoulutuksella on positiivinen palkkavaikutus. 1990-luvulla se oli jopa epäilyttävän suuri, keskimäärin 1-2 prosenttia noin viikon pituista kurssia kohti. Epäilyttävän suuret tuotot näyttäisivät kuitenkin olevan alan kirjallisuuden yleinen ongelma (Leuven 2004 ja 2005; Pischke
2005), eivätkä koske vain minun tuloksiani.

Mutta miten nämä inhimillisen pääoman tuotot ovat kehittyneet? Onko muutoksella jokin suunta? Ja jos on, miten se vastaa arkikäsitystämme? Näihin kysymyksiin etsin seuraavassa vastausta empiirisen tutkimuksen menetelmin. Aineistona ovat vuosina 1990, 1995, 2000 ja 2006 kootut aikuiskoulutustutkimukset.

\section{MALLIA KOSKEVA KESKUSTELU}

Koulutuksen palkkavaikutuksen estimointi on viimeisen sukupolven aikana perustunut yleensä Jacob Mincerin kehittämään tilastolliseen ansiofunktioon (Mincer 1974). Mallissa selitettävän paikalla on yleensä bruttovuosi- tai kuukausipalkan logaritmi. Se, että tässä artikkelissa selitettävänä on laskennallisen bruttotuntipalkan logaritmi tarkoittaa sitä, että työpanos (työntuntien vaihtelu) on vakioitu. Toinen, tulkintoja helpottava ero tulee kaupan päälle: tunti- 
palkan kuvaaja yli elinkaaren on likimain lineaarinen, kun runsas osa-aikatyö ikäjakauman molemmissa päissä karsiutuu pois (Laukkanen 2010, 55).

Selittäjinä mallissa ovat yleensä laskennalliset koulutus- ja työkokemusvuodet sekä joukko vakioitavia taustamuuttujia, kuten sukupuoli ja toimiala. Perusmallissa kaikki koulutusasteen X suorittaneet ovat oletuksen mukaan valmistuneet Y vuodessa. Esimerkiksi kaikki ylemmän keskiasteen tutkinnon suorittaneet ovat - peruskoulu mukaan lukien - valmistuneet 12 vuodessa. Se on aika rajoittava oletus ja ristiriidassa havaintojemme kanssa. ${ }^{1}$ Siksi seuraavassa koulutusasteen palkkavaikutus, suhteessa perusasteen tutkintoon, estimoidaan indikaattorimuuttujilla tilastokeskuksen koulutusasteluokituksen mukaan.

Työkokemusvuodet on kuitenkin kysytty. Ja hyvä niin, sillä laskennalliset työkokemusvuodet - ikä vähennettynä koulunaloittamisikä ja laskennalliset koulutusvuodet - eivät olisi sallineet jakoa työkokemusvuosiin nykyisellä työpaikalla (senioriteetti) ja muilla työpaikoilla. Joustoturvaa, EU:n uutta työmarkkinamallia arvioitaessa tällä jaolla on huomattava periaatteellinen merkitys. Joustoturvassa ammatillisen liikkuvuuden merkitystä korostetaan senioriteetin ja työsuhdeturvan kustannuksella (Tros \& Wilthagen 2004). Tavoitteeksi on asetettu "liiallisen" työsuhdeturvan karsiminen siten, että työpaikkaliikkuvuus voisi lisääntyä (EU 2006). Välittäväksi tekijäksi nostetaan koulutus, joka joustoturvan yleisissä periaatteissa mainitaan yhteensä 94 kertaa (EU 2007). ${ }^{2}$

Väljin ilmaisumuoto työllisyysturvaa parantavalle koulutukselle on kuitenkin elinikäinen oppiminen, life-long learning, jossa oppimismuodot ovat varsin vapaat (EU, 2011). Sen käsitteen varaan lasketaan nykyään aika paljon siinä rakennemuutoksessa, jossa uusia työpaikkoja luodaan taitotasoa kohottamalla. Ja siksi niin Suomen kuin EU:nkin kasvustrategiat ovat nykyään osaamisintensiivisiä (Valtioneuvosto 2004; EU, 2004, 2008). Näissä strategioissa menestyksemme niin talouksina kuin yksilöinä riippuu inhimillisestä pääomastamme. ${ }^{3}$

Viime vuosina tällaista koulutusoptimismia on myös kritisoitu. On sanottu, että vaikka koulutuksella onkin palkkavaikutus, aivan kaikkia ongelmia, kuten sujuvaa siirtymistä supistuvilta aloilta kasvaville aloil- le, se ei ratkaise. Palkansaajilla tärkeimmät arvot ovat työsuhdeturva ja urakehitys nykyisellä työpaikalla. Jos nämä arvot sivuutetaan ja aikuiskoulutuksessa keskitytään palkansaajille vastentahtoisten työstätyöhön -siirtymien edistämiseen, osalle koulutuksesta voi tulla pakkopullaa jonka tuottavuusvaikutus on kyseenalainen. Myös jako työmarkkina-asemaltaan vahvaan ydintyövoimaan ja epävarmuudesta kärsivään reunatyövoimaan voi voimistua (Keune, 2008; Tangian, 2011; Barroni \& Keune, 2011).

Paljon tosin riippuu koulutus- ja työmarkkinamallistamme: koulutus- ja palkkapolitiikasta sekä neuvottelutasapainosta työpaikoilla. Suomessa 85-90 prosenttia kaikista vuoden aikana hankituista ammatillisen aikuiskoulutuksen tapahtumista on työnantajan rahoittamaa henkilöstökoulutusta, jonka tarve seuraavalle vuodelle tulee arvioida yhteistoimintalain mukaan yhteisöllisesti ja henkilöstöryhmittäin. ${ }^{4}$ Aikuiskoulutukseen valikoitumiseen en tässä puutu aineiston rajoitusten vuoksi. ${ }^{5}$

Aiemmissa julkaisuissani olen päätynyt siihen, että aikuiskoulutuksen sisällyttäminen malliin laskee peruskoulutukselle ja työkokemukselle estimoitua tuottoa (Laukkanen 2010), että ammatillisen aikuiskoulutuksen palkkavaikutus saattaa olla ehtymässä (Laukkanen 2011a) ja että koulutusasteiden väliset erot aikuiskoulutuksen jakautumisessa ovat 2000-luvulla supistuneet (Laukkanen 2011 b). Tässä artikkelissa täsmennän analyysiä siten, että myös muut inhimillisen pääoman muodot, kuten ammatillinen peruskoulutus ja työkokemus tulevat aiempaa paremmin huomioiduiksi. ${ }^{6}$

\section{AINEISTO}

Käytössäni ovat tilastokeskuksen koostamat aikuiskoulututkimukset vuosilta 1990, 1995, 2000 ja 2006. Eri vuosien aineistoilla on omat erityispiirteensä, mutta onneksi yhtäläisyyksiäkin löytyy siinä määrin, että inhimillisen pääoman eri muotojen palkkavaikutus on vähintään tilastollisen ansiofunktion edellyttämällä tarkkuudella estimoitavissa. ${ }^{7}$ Tutkimuksen perusjoukon muodostavat 25-64-vuotiaat palkansaajat $^{8}$, liitetaulukossa 1 kuvatulla tavalla.

Tarkastelujaksolla palkansaajien koulutustaso on noussut: perusasteen tutkinnon varassa työskentele- 
vien osuus on pudonnut 32 prosentista 14 prosenttiin. Sen verran palkansaajistamme edelleen tekee työtään ilman ammatillisesti eriytyvää koulutusta. Myös työuran aikana hankittu "ammattiin tai työhön liittyvä aikuiskoulutus", kuten asia aikuiskoulutustutkimuksen lomakkeessa täsmennetään, on lisääntynyt. Vuonna 199016 prosenttia palkansaajista teki työtään, ilman että työuran aikana olisi käynyt yhtään kurssia ammatillista aikuiskoulutusta. Vuonna 2006 heitä oli enää yhdeksän prosenttia. Yli 10 kurssia oli vuonna 1990 saanut 35 prosenttia ja vuonna 2006 joka toinen palkansaaja.

Kolmas inhimillisen pääoman muoto on työkokemus, jaettuna työkokemukseen nykyisellä työpaikalla (senioriteetti) ja muualla. Työvuosien määrät nykyisellä työpaikalla ovat koko ajan olleet keskimäärin 10-11 vuotta. Siten senioriteetti keskimäärin ei ole heikentynyt, mutta toisaalta senioriteetin hajonta on kasvanut. Tämä voi tarkoittaa vain sitä, että senioriteetti pakkautuu aiempaa vähemmän keskiarvon tuntumaan. On entistä enemmän sekä keskimääräistä lyhyempää että pitempää senioriteettia. Työkokemusvuodet muualla ovat koko ajan olleet yhdeksän vuoden tuntumassa, ja myös näiden vuosien keskihajonta on ajan saatossa kasvanut, mutta huomattavasti vähemmän kuin senioriteetin kohdalla.

Muut taustamuuttujat, kuten työpaikan toimintasektori, löytyvät liitetaulukosta 1 , enkä niihin jatkossa enää viittaa. Olen vain halunnut vakioida nämä tekijät inhimillistä pääomaa koskevien päätelmieni tieltä. Myönnän toki, että vakioitavien taustamuuttujien määrä olisi voinut olla suurempi. Mutta tämäkin tutkimus on tehty aineiston ehdoilla. Työpaikalla mahdollisesti käytössä olevista tulospalkoista tai ryhmätyön muodoista, joilla on voinut olla suora palkkavaikutus, ei aikuiskoulutustutkimuksissa ole kysytty.

Avaintulokset esitän kuvioina. Koko mallia koskevat tulokset ovat liitetaulukkona artikkelin lopussa.

\section{INHIMILLISEN PÄÄOMAN PALKKAVAIKUTUS}

\section{Koulutusasteen palkkavaikutus}

Koulutusasteen palkkavaikutusta arvioitaessa yksi ongelma on vuosi 1995, ensimmäinen pitkäkestoisen talouslaman jälkeinen kasvuvuosi, jolloin koulutuksesta maksettiin lähes kaikilla koulutusasteilla vähemmän kuin vuosina 1990 ja 2000. Ilman tätä pientä tasopudotusta tarkastelujakson kehityskuva olisi yhtenäisempi. Sen kehityskuvan mukaan nuorisoasteen koulutuksen tuotot ovat laskussa, vaikkakin hitaasti, eivätkä aivan yhtenäisesti ja kiistatta.

Kun vertailukohtana pidetään perusasteen tutkinnon suorittaneiden tuntipalkkoja, hyöty keskiasteen ammatillisista perustutkinnoista on tarkastelujaksolla ollut vain marginaalinen, jos sitäkään. Vuonna 1990 keskiasteen tutkinnon suorittaneet saivat keskimärin 9 prosenttia parempaa tuntipalkkaa kuin perusasteen suorittaneet. Vuosina 1995 ja 2000 ero kutistui niin pieneksi, että tilastollisesti merkitsevää eroa nollasta ei enää ollut. Vuonna 2006 ero oli kohonnut taas seitsemän prosenttiin. Kovin suurta hyötyä ammatillisesta, keskimäärin kolmen vuoden pituisesta perustutkinnosta, ei silti voi sanoa olevan, kun yksi

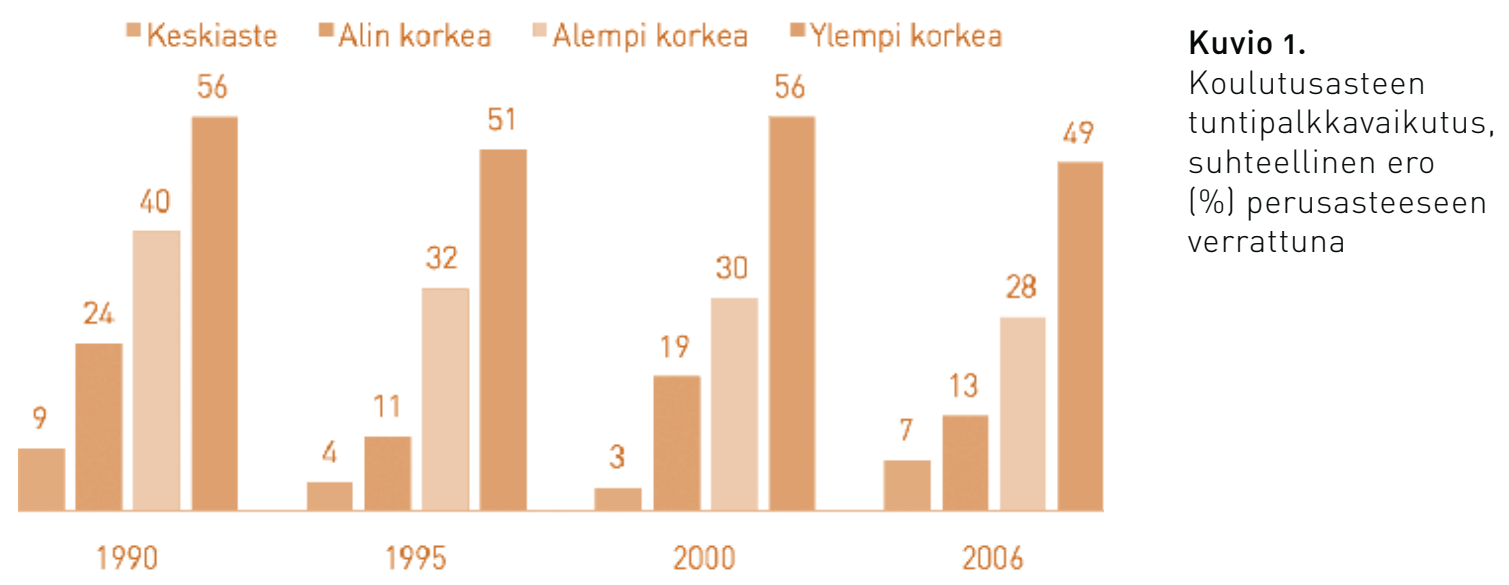


lisävuosi koulutusta nostaa tuntipalkkaa vain pari prosenttia. Motivoiko se jatkamaan perusasteelta keskiasteelle ja viemään opinnot päätökseen?

Alimman korkea-asteen suorittaneiden palkkaero perusasteen tutkinnon suorittaneisiin oli 24 prosenttia vuonna 1990, mutta enää 13 prosenttia vuonna 2006. Alemmalla korkea-asteella vastaavat luvut ovat 40 prosenttia vuonna 1990 ja 28 prosenttia vuonna 2006. Ylemmällä korkea-asteella ne ovat 56 prosenttia vuonna 1990 ja 49 prosenttia vuonna 2006. Suhteessa perusasteeseen korkea-asteen tutkinnot näyttäisivät siis menettäneen palkalla mitattua taloudellista arvoaan. Suhteellisesti vähiten arvoaan ovat kuitenkin menettäneet ylemmän korkea-asteen tutkinnot. Toisin sanoen, ylemmän korkea-asteen suhteellinen asema korkea-asteen sisällä on parantunut.

\section{Työkokemusvuoden palkkavaikutus}

Vuodet nykyisellä työpaikalla mittaavat työsuhteen vakautta, senioriteettia, ja samalla myös työpaikalle ominaisten taitojen (firm-specific skills) tasoa, jotka taidot ovat omiaan vahvistamaan työntekijän asemaa työpaikan muutostilanteissa, kuten tuotannollisten ja taloudellisten vaikeuksien ilmaantuessa. Jos senioriteetista ei ole mitään erityistä etua, kuten joustoturvassa annetaan ymmärtää, työkokemusvuosien muilla työpaikoilla tulisi nostaa palkkaa samalla tavalla kuin työkokemusvuosien nykyisellä työpaikalla.

Näin ei kuitenkaan näyttäisi olevan. Yksi työkokemusvuosi nykyisellä työpaikalla on koko tarkastelujakson ajan tuottanut enemmän kuin yksi työkokemusvuosi muilla työpaikoilla. 1990-luvulla senioriteettiin liittyvä etu saattoi tosin pienentyä absoluuttisesti, pylväitten (piste-estimaattien) erotuksella mitattuna, mutta ei suhteellisesti, jakamalla kuvion 2 ensimmäinen pylväs toisella. Vuonna 1990 senioriteettiin liittyvä suhteellinen etu oli 1,5, vuonna 2000 se oli $1,9$.

Olennaisin muutos on kuitenkin se, että työkokemuksen palkkavaikutus on supistunut. 1990-luvulla yksi työkokemusvuosi nosti tuntipalkkaa keskimäärin noin prosentin. 2000-luvulla yksi työkokemusvuosi nosti palkkaa enää 0,4-0,6 prosenttia. Ja mitä muissa työpaikoissa hankittuun työkokemukseen tulee, niin vuonna 2006 sen tuntipalkkavaikutus oli tilastollisesti nolla. Silloin merkitystä oli enää senioriteetilla, omalla työpaikalla hankitulla työkokemuksella. Työkokemus muilla työpaikoilla oli menettänyt arvonsa.

Jos aineistossa olisi ollut tietoja esimerkiksi tulospalkoista ja tuotantopalkkioista, ikälisäjärjestelmistä tai ryhmä- ja tiimityön muodoista, selitys näille muutoksille olisi mahdollisesti löytynyt. Mutta ikävä kyllä, näitä tietoja aineistossa ei ole. Siten selitystä sille, mistä tekijöistä työkokemuksen palkkavaikutuksen pienentyminen nousee, on haettava yleisemmältä tasolta, työmarkkinajärjestelmässämme tapahtuneista muutoksista.

\section{AMMATILLISEN AIKUISKOULUTUSKURSSIEN PALKKAVAIKUTUS}

Ammatillinen aikuiskoulutus voi olla poikkeus yleisestä, inhimillisen pääoman tuottoa koskevasta pitkän

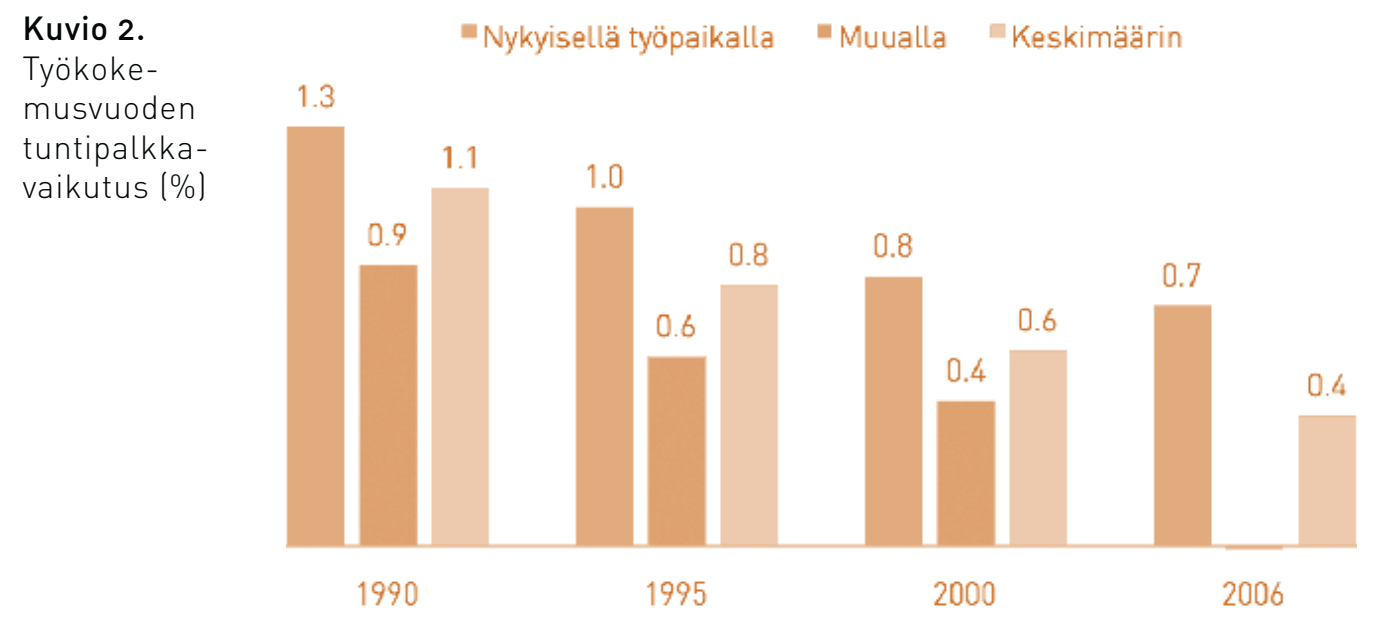


-1-3 kurssia $\quad$-4-10 kurssia "yli 10 kurssia

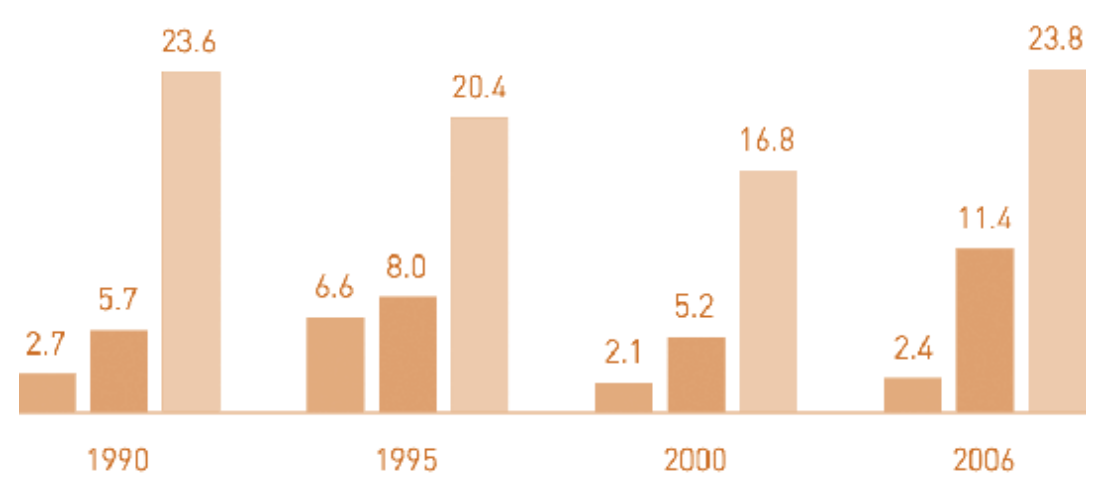

\section{Kuvio 3}

Aikuiskoulutuskurssien

tuntipalkkavaikutus

(\%) kurssittamattomiin

verrattuna aikavälin kehityskuvasta. Joka tapauksessa kehityskuva on huomattavasti epäyhtenäisempi kuin ammatillisen peruskoulutuksen (koulutusaste) ja työkokemuksen tapauksessa. Jaksolla 1990-2000 erityisesti runsas, yli 10 aikuiskoulutuskurssia kattava koulutus menetti palkkavaikutuksella mitattua arvoaan.

Mutta vuonna 2006 aikuiskoulutuskurssin palkkavaikutus on palannut vuoden 1990 tasolle. Myös sitä vähäisemmän kurssikertymän palkkavaikutus on kaikissa tarkastelujakson mittauksissa positiivinen ja tilastollisesti merkitsevä, mutta vain siinä tapauksessa, että aikuiskoulutuskursseja on paljon. Muutamilla kursseilla ei tilastollisesti merkitsevää palkkavaikutusta ole. Tämä johtuu piste-estimaattien suurista keskivirheistä, ja siksikin kehityskuvasta yli ajan tulee varsin epäyhtenäinen.

Kehityskuvan selventämiseksi jalostin indikaattorimuuttujista laskennallisen jatkuvan muuttujan antamalla kullekin palkansaajalle kurssien määräksi sen luvun, joka on indikaattorimuuttujan keskikohta. ${ }^{9}$ Näin menetellen piste-estimaattien etumerkeistä tulee tilastollisesti erittäin merkitseviä ja kehityskuva aikuiskoulutuksen palkkavaikutuksesta selkenee. ${ }^{10}$ Vuonna 1990 yksi laskennallinen ammatillinen aikuiskoulutuskurssi nosti tuntipalkkaa 1.7 prosenttia. Siitä se laski vuoteen 2000 mennessä 1,2 prosenttiin ja nousi taas 1,6 prosenttiin vuonna 2006.

Nämä tulokset ovat likimain samat kuin kilpailevassa mallispesifikaatiossa, jossa työkokemusta ja ammatillista peruskoulutusta (koulutusaste) on mitattu karkeammin (Laukkanen 2011a). Tämä taas kielii siitä, käyttämäni elinkaarimalli on varsin vakaa. Mallitäsmennyksillä on vain marginaalinen vaikutus avaintuloksiin, inhimilliselle pääomalle estimoituu tuottoon, kuten Rita Asplund (2000) on Suomea koskevissa tutkimuksissaan jo aiemmin huomannut.

Edellä esitetystä voi siten päätellä, että 2000-luvulla aikuiskoulutuksen suhteellinen arvo, ammatilliseen peruskoulutukseen (koulutusastekoulutukseen) verrattuna, on parantunut. Syynä siihen ovat voineet olla näyttötutkinnot, joiden märä on 2000-luvulla kasvanut, ja siihen liittyvä kurssitus, sekä noste-ohjelma vuodesta 2003 lähtien. Niissä molemmissa ovat kohderyhminä olleet vähiten koulutetut, jotka omien tutkimusteni mukaan hyötyvät aikuiskoulutuksesta eniten (Laukkanen 2010, 68).

\section{KOULUTUKSEN MUUT VAIKUTUKSET}

Ennen yhteenvetoa ja johtopäätösten tekoa on kuitenkin syytä katsoa, mitä muita kuin palkkavaikutuksia työuran aikana hankitulla aikuiskoulutuksella on voinut olla. Taulukkoon 1 on koottu ne vaikutukset, joista kaikissa tai likimain kaikissa tarkastelukauden kyselyissä on kysytty. Kysymykset olen luokitellut kyllä-ei-asteikolle, ja taulukossa on esitetty kyllävastausten osuus.

Tärkeimmäksi vaikutukseksi (54 prosenttia vuonna 2006) osoittautuu horisontaalinen liikkuvuus työpaikan sisällä - se, että koulutus auttoi saamaan uusia tehtäviä. Toiseksi tärkeimmäksi (42 prosenttia vuonna 2006) osoittautuu vertikaalinen liikkuvuus työpaikan sisällä - se, että koulutus auttoi siirtymään vaativampiin työtehtäviin. Kolmanneksi tärkeimmäksi (37 prosenttia vuonna 2006) osoittautuu työsuhdeturva - se, että koulutus auttoi säilyttämään työpaikan. Näistä horisontaalisen ja vertikaalisen liikkuvuuden merkitys näyttäisi tarkastelujaksolla selvästi kasvaneen. 


\begin{tabular}{|c|c|c|c|c|c|}
\hline \multirow[b]{2}{*}{ järj. } & \multirow[b]{2}{*}{ Vaikutus } & \multicolumn{4}{|c|}{ vuosi } \\
\hline & & 1990 & 1995 & 2000 & 2006 \\
\hline 1 & Auttoi saamaan uusia tehtäviä. & 21 & 47 & 52 & 54 \\
\hline 2 & Auttoi siirtymään vaativampiin tehtäviin. & 36 & 38 & 43 & 42 \\
\hline 3 & Auttoi säilyttämän työpaikan. & & 33 & 32 & 37 \\
\hline 4 & Auttoi saamaan lisää palkkaa. & & 23 & 24 & 26 \\
\hline 5 & Auttoi vakituisen työpaikan saamisessa. & 19 & 21 & 21 & 25 \\
\hline \multirow[t]{2}{*}{6} & Auttoi vaihtamaan työpaikkaa tai ammattia. & 15 & 12 & 16 & 15 \\
\hline & N & 1653 & 1659 & 1580 & 2363 \\
\hline
\end{tabular}

Taulukko 1.

Subjektiivinen arvio työuran aikana hankittujen aikuiskoulutuskurssien vaikutuksista, \% 24-64-vuotiaista palkansaajista
Vasta neljänneksi tärkeimpänä vaikuttimena (26 prosenttia vuonna 2006) mainitaan palkka - se, että koulutus auttoi saamaan lisää palkkaa. Palkan merkitys on jaksolla 1995-2006, sinä aikana kun siitä on kysytty, ollut likimain sama. Heti palkan jälkeen tulee taas työsuhdeturvaan liittyvä vaikutin - se, että koulutus auttoi vakituisen työpaikan saamisessa (25 prosenttia vuonna 2006). Sen merkitys näyttäisi 2000-luvulla selvästi lisääntyneen. Viimeiseksi jää joustoturvan alleviivaama työpaikkaliikkuvuus - se, että koulutus auttoi vaihtamaan työpaikkaa tai ammattia (15 prosenttia vuonna 2006).

Näiden vaikuttimien keskinäisen riippuvuudet näkyvät korrelaatiomatriisista liitetaulukossa 3. Sen mukaan kahden tärkeimmän vaikuttimen - työpaikan sisäisen horisontaalisen ja vertikaalisen liikkuvuuden - välillä vallitsee vahva positiivinen riippuvuus. Työpaikan sisäinen liikkuvuus korreloi vahvasti myös palkkakehityksen kanssa indikoiden sitä, että ammatillisen aikuiskoulutuksen palkkavaikutus on olennainen osa työpaikan sisäistä liikkuvuutta, vaikka sitä subjektiivisessa arvioinnissa ei kovin tärkeäksi asiaksi tunnusteta.

\section{PÄÄTELMÄT}

1990-luvulla inhimillisen pääoman palkkavaikutus supistui. Supistuminen koski kaikkia tässä tarkasteltuja inhimillisen pääoman muotoja: ammatillista peruskoulutusta (koulutusastein mitaten), työkokemusvuosia ja työuran aikana käytyjä ammatillisia aikuiskoulutuskursseja. 2000-luvulla ammatillisen aikuiskoulutuksen palkkavaikutus on taas voimistunut. Sen sijaan työkokemuksen palkkavaikutus on jatkanut supistumistaan, ja muualla kuin nykyisellä työpaikalla, hankittu työkokemus on menettänyt palkkavaikutuksensa tyystin.

Käytettävissä olevasta aineistosta ei löydy suoraa selitystä sille, miksi palkkavaikutus on supistunut. Aineisto kun ei kata tietoja työn organisoinnissa ja palkkausjärjestelmissä tapahtuneista muutoksista, joista olisi hyvinkin voinut löytyä ainakin osaselitys inhimillisen pääoman palkkavaikutuksen heikentymiselle. Mutta toki vastausta voi etsiä myös yleisemmältä tasolta, kuten työmarkkinamallissamme tapahtuneista muutoksista, jotka työn uudelleenorganisoimisen ja uudet palkkausjärjestelmät ovat tehneet mahdollisiksi.

1990-luvulta lähtien työmarkkinamalliamme on kehitetty entistä joustavampaan suuntaan. EU:ssa tämän keskustelun kehykseksi on noussut joustoturva, "joustavuus inhimillisen kasvoin", ja 2000-luvulla se on hallinnut myös suomalaista keskustelua, muutosturvan nimellä. Joustoturvassa koulutus erityisesti ammatillinen aikuiskoulutus - on erittäin keskeisessä asemassa. Oletuksen mukaan koulutus ohjaa palkansaajia työstä työhön, kuten supistuvilta aloilta kasvaville aloille, niin tehokkaasti, että senioriteetista, työkokemuksesta omalla työpaikalla ei ole enää mitään erityistä hyötyä. Tätä näkemystä yllä esitetyt tulokset eivät tue. Siksi joustoturvan oletuksia koskevan keskusteluun olisi syytä palata.

Se, että koulutusasteen palkkavaikutus on heikentynyt, ei ole iso uutinen kun ottaa huomioon sen miten pienestä ja jopa kyseenalaisesta muutoksesta on kysymys. Jaksolla 1990-2006 palkansaajien koulutustaso on parantunut niin paljon, että sillä on var- 
masti ollut vaikutusta myös koulutetun työvoiman kysyntä ja tarjonta -asetelmaan. Koulutustaso sinänsä ei ilmeisesti enää paina niin paljon kuin ennen, mutta koulutusalan merkitys on voinut kasvaa. Kysymyksen voi asettaa myös toisin päin: miksi koulutusasteen palkkavaikutus on heikentynyt niin vähän?

Kiinnostavin ja samalla myös ongelmallisin tulos koskee ammatillisen aikuiskoulutuksen ja työkokemuksen välistä suhdetta. Jos työkokemuksesta nykyisellä työpaikalla hyötyy selvästi enemmän kuin työkokemuksesta muilla työpaikoilla, niin palkansaajilla on motiivi suosia sellaisia koulutusjärjestelyjä, jotka tukevat urakehitystä nykyisellä työpaikalla. Ja näin näyttäisi myös tapahtuneen. Työuran aikana hankittu ammatillinen aikuiskoulutus on vaikuttanut eniten työpaikan sisäiseen liikkuvuuteen, jonka kanssa myös aikuiskoulutuksen palkkavaikutus vahvasti korreloi. Mutta ammatillisten siirtymien tukena, kuten työpaikan tai ammatin vaihdossa, aikuiskoulutuksen rooli on pysynyt vaatimattomana.

Lopuksi on syytä todeta, että edellä esitetyt tulokset nousevat käytetystä mallista ja käytettävissä ol- leesta aineistosta. Jollakin toisella mallilla ja aineistolla tulokset olisivat voineet olla toiset. Itse olen kuitenkin sitä mieltä, että elinikäisen oppimisen tutkimiseen tarvitaan elinkaarimalli, jonka puitteissa on mahdollista tarkastella useampia inhimillisen pääoman muotoja samanaikaisesti.

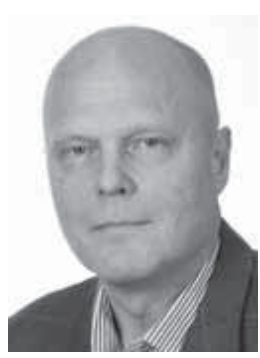

Erkki Laukkanen

Taloustieteen tohtori ekonomisti työllisyyden ja kestävän kasvun linja Suomen Ammattijärjestöjen Keskusliitto SAK, Helsinki

KIRJALLISUUS:

Asplund, R. Pereira, P. T. (Eds) (1999). Returns to human capital in Europe. A Literature Review. The Research Institute of the Finnish Economy, B 156, Helsinki.

Asplund, R. (2000). Private returns to education in Finland: back to basics. The Research Institute of the Finnish Economy, DP 720, Helsinki.

Barroni, L. \& Keune, M. (2011). Flexicurity: a conceptual critique. European Journal of Industrial Relations, 17: 75.

EU (2004). Education and training 2010. Joint interim report of the Council and the Commission on the implementation of the detailed work programme on the follow-up of the objectives of education and training systems in Europe. Council of the European Union, Brussels, 3 March 2004.

EU (2007). Towards common principles of flexicurity: more and better jobs through flexibility and security. European Commission, Brussels. http://ec.europa. eu/social/BlobServlet?docld=2756andlangld=en
EU (2008). New skills for new jobs - Anticipating and matching labour market and skills needs. Communication from the Commission to the European Parliament, the Council, the European Social Committee and the committee of the Regions. Brussels, 16.12.2008, COM(2008) 868 final.

EU (2010). Communication from the Commission, Europe 2020: A strategy for smart, sustainable and inclusive growth.

EU (2011). Mid term review of the Lifelong Learning Programme. COM(2011) 413 final. http:// eur-lex.europa.eu/LexUriServ/LexUriServ. do?uri=COM:2011:0413:FIN:EN:PDF

Keune, M. (2008). Flexicurity: the new cure for Europe's labour market problems? Teoksessa Degryse, Ch., and P. Pochet (toim.) Social Developments in the European Union 2007. Brussels: ETUI-REHS. 
Laukkanen, E. (2010). Wage returns to training: evidence from Finland. Studies 110. Helsinki: Labour Institute for Economic Research.

Laukkanen, E. (2011a). Aikuiskoulutus kannattaa, mutta kuinka kauan? Talous- ja yhteiskunta, 2/2011.

Laukkanen, E. (2011b). Education - training complementarity in Finland. http://www.iaq.uni-due. de/iwplms/papers/IWPLMSpaper_Laukkanen. pdf. Ilmestyy myös CEDEFOP:n julkaisusarjassa syksyllä.

Leuven, E. (2004). A review of the wage returns to private sector training. EC-OECD Seminar on Human Capital and Labour Market Performance, Brussels 8.12.2004.

Leuven, E. (2005). The economics of private sector training: a survey of the literature. Journal of Economic Surveys, 19(1).

Mincer, J. (1974). Schooling, experience and earnings. NBER, New York.

Mincer, J. (1989). Job training: costs, returns, and wage profiles. NBER Working Paper No. 3208.

\section{Liitetaulukko 1. Aineisto}

\begin{tabular}{|l|c|c|c|c|}
\hline Muuttujat & 1990 & 1995 & 2000 & 2006 \\
\hline $\begin{array}{l}\text { Tuntipalkka vuoden 2006 } \\
\text { rahassa }\end{array}$ & 10.84 & 12.97 & 15.56 & 16.99 \\
\hline Edellisen keskihajonta & 8.03 & 11.84 & 14.03 & 11.59 \\
\hline Taustamuuttujat & & & & \\
\hline Mies & 0.50 & 0.49 & 0.50 & 0.50 \\
\hline Uusimaa & 0.24 & 0.28 & 0.31 & 0.28 \\
\hline Alkutuotanto & 0.03 & 0.04 & 0.03 & 0.02 \\
\hline Jalostus & 0.31 & 0.28 & 0.27 & 0.24 \\
\hline Yksityinen palvelu & 0.31 & 0.33 & 0.32 & 0.38 \\
\hline Julkinen palvelu & 0.35 & 0.35 & 0.38 & 0.35 \\
\hline Koulutusaste & & & & \\
\hline Perusaste & 0.32 & 0.23 & 0.19 & 0.14 \\
\hline Keskiaste & 0.38 & 0.37 & 0.40 & 0.43 \\
\hline Alin korkea & 0.17 & 0.20 & 0.21 & 0.19 \\
\hline Alempi korkea & 0.06 & 0.08 & 0.09 & 0.12 \\
\hline Ylempi korkea & 0.07 & 0.11 & 0.11 & 0.12 \\
\hline Työkokemus & & & & \\
\hline Vuodet nykyisellä työpaikalla & 10.48 & 10.54 & 10.95 & 10.92 \\
\hline Edellisen keskihajonta & 9.07 & 9.16 & 9.82 & 11.40 \\
\hline
\end{tabular}

\begin{tabular}{|l|l|l|l|l|}
\hline Vuodet muualla & 9.77 & 8.74 & 9.81 & 9.12 \\
\hline Edellisen keskihajonta & 8.77 & 8.15 & 8.96 & 9.20 \\
\hline Ammatilliset kurssit & & & & \\
\hline Ei yhtään kurssia & 0.16 & 0.12 & 0.09 & 0.09 \\
\hline 1-3 kertaa & 0.26 & 0.19 & 0.17 & 0.17 \\
\hline 4-10 kertaa & 0.23 & 0.26 & 0.24 & 0.24 \\
\hline yli 10 kertaa & 0.35 & 0.44 & 0.51 & 0.50 \\
\hline $\mathrm{N}$ & 1850 & 1716 & 1733 & 2538 \\
\hline
\end{tabular}




\begin{tabular}{|c|c|c|c|c|c|c|c|c|}
\hline \multirow{2}{*}{ Selittävät muuttujat } & \multicolumn{2}{|c|}{1990} & \multicolumn{2}{|c|}{1995} & \multicolumn{2}{|c|}{2000} & \multicolumn{2}{|c|}{2006} \\
\hline & Kerroin & Keskivirhe & Kerroin & Keskivirhe & Kerroin & Keskivirhe & Kerroin & Keskivirhe \\
\hline \multicolumn{9}{|l|}{ Taustamuuttujat } \\
\hline Mies & 0.22 & 0.03 & 0.18 & 0.02 & 0.18 & 0.02 & 0.21 & 0.02 \\
\hline Uusimaa & 0.15 & 0.03 & 0.10 & 0.03 & 0.08 & 0.03 & 0.12 & 0.02 \\
\hline Jalostus & 0.25 & 0.10 & 0.06 & 0.06 & 0.16 & 0.05 & 0.20 & 0.07 \\
\hline Yksityiset palvelut & 0.19 & 0.10 & 0.05 & 0.07 & 0.14 & 0.05 & 0.12 & 0.07 \\
\hline Julkiset palvelut & 0.26 & 0.09 & 0.11 & 0.06 & 0.08 & 0.05 & 0.12 & 0.07 \\
\hline \multicolumn{9}{|c|}{ Koulutusaste, perusasteeseen verrattuna } \\
\hline Keskiaste & 0.09 & 0.04 & 0.04 & 0.03 & 0.03 & 0.03 & 0.07 & 0.03 \\
\hline Alin korkea & 0.24 & 0.05 & 0.11 & 0.04 & 0.19 & 0.04 & 0.13 & 0.04 \\
\hline Alempi korkea & 0.40 & 0.06 & 0.32 & 0.05 & 0.30 & 0.04 & 0.28 & 0.04 \\
\hline Ylempi korkea & 0.56 & 0.07 & 0.51 & 0.06 & 0.56 & 0.07 & 0.49 & 0.04 \\
\hline \multicolumn{9}{|l|}{ Työkokemusvuodet } \\
\hline Nyk. työnantajalla & 0.01 & 0.00 & 0.01 & 0.00 & 0.01 & 0.00 & 0.01 & 0.00 \\
\hline Muualla & 0.01 & 0.00 & 0.01 & 0.00 & 0.00 & 0.00 & 0.00 & 0.00 \\
\hline \multicolumn{9}{|c|}{ Aikuiskoulutuskurssit, kurssittamattomiin verrattuna } \\
\hline 1-3 kurssia & 0.03 & 0.05 & 0.07 & 0.05 & 0.02 & 0.05 & 0.02 & 0.03 \\
\hline 4-10 kurssia & 0.06 & 0.05 & 0.08 & 0.05 & 0.05 & 0.05 & 0.11 & 0.03 \\
\hline Yli 10 kurssia & 0.24 & 0.05 & 0.20 & 0.05 & 0.17 & 0.05 & 0.24 & 0.03 \\
\hline Vakio & 1.48 & 0.10 & 1.78 & 0.08 & 1.91 & 0.07 & 2.07 & 0.08 \\
\hline N & 1850 & & 1716 & & 1733 & & 2538 & \\
\hline Selitysaste & 0.1734 & & 0.1836 & & 0.2197 & & 0.2595 & \\
\hline
\end{tabular}

Liitetaulukko 2.

Koulutuksen ja työkokemuksen tuntipalkkavaikutus, \% / 100

Liitetaulukko 3. Koulutusvaikutusten korrelaatiomatriisi

\begin{tabular}{|c|c|c|c|c|c|c|}
\hline $\begin{array}{l}\text { Ammatillinen } \\
\text { aikuiskoulutus } \\
\text { auttoi... }\end{array}$ & $\begin{array}{l}\text { saamaan lisää } \\
\text { palkkaa }\end{array}$ & $\begin{array}{c}\text { saamaan uusia } \\
\text { tehtäviä }\end{array}$ & $\begin{array}{c}\text { siirtymään } \\
\text { vaativampiin } \\
\text { tehtäviin }\end{array}$ & $\begin{array}{l}\text { vaihtamaan } \\
\text { työpaikkaa tai } \\
\text { ammattia }\end{array}$ & $\begin{array}{c}\text { vakituisen työpai- } \\
\text { kan saamisessa }\end{array}$ & $\begin{array}{l}\text { säilyttämän } \\
\text { työpaikan }\end{array}$ \\
\hline $\begin{array}{l}\text { saamaan lisää } \\
\text { palkkaa }\end{array}$ & 1 & & & & & \\
\hline $\begin{array}{l}\text { saamaan uusia } \\
\text { tehtäviä }\end{array}$ & 0.3804 & 1 & & & & \\
\hline $\begin{array}{l}\text { siirtymään } \\
\text { vaativampiin } \\
\text { tehtäviin }\end{array}$ & 0.4138 & 0.5917 & 1 & & & \\
\hline $\begin{array}{l}\text { vaihtamaan } \\
\text { työpaikkaa tai } \\
\text { ammattia }\end{array}$ & 0.2165 & 0.2359 & 0.2441 & 1 & & \\
\hline $\begin{array}{l}\text { vakituisen } \\
\text { työpaikan } \\
\text { saamisessa }\end{array}$ & 0.218 & 0.2232 & 0.2119 & 0.314 & 1 & \\
\hline $\begin{array}{l}\text { säilyttämän } \\
\text { työpaikan }\end{array}$ & 0.2017 & 0.2106 & 0.2351 & 0.1251 & 0.2649 & 1 \\
\hline
\end{tabular}


1 Vuodesta 1995 lähtien aikuiskoulutustutkimuksessa on kysytty myös todellisia koulutusvuosia. Tilastokeskuksen käyttämiin normivuosiin verrattuna todelliset koulutusvuodet ovat lyhyempiä keskiasteella ja pitempiä korkea-asteella.

2 Joustoturvaa on esitelty myös työvoimapolitiikan mallina, mutta joustoturvan yleisissä periaatteissa sillä on vain marginaalinen rooli. Se mainitaan vain kolme kertaa.

3 Esimerkki kasvukeskeisestä koulutusajattelusta (EU 2020,17): "Inclusive growth means empowering people through high levels of employment, investing in skills, fighting poverty and modernising labour markets, training and social protection systems so as to help people anticipate and manage change, and build a cohesive society."

4 Yhteistoimintalaki, 1978, 6b $\S ; 2007,16 \S$.

5 Tämä pätee ainakin vuosien 1990 ja 1995 aineistoihin. Väitöskirjani luvussa 6 olen valikoitumisen ottanut huomioon siinä määrin kuin vuoden 2000 aineisto sen salli. Tulos oli, että valikointi vaikuttaa aikuiskoulutuksen tuottoon, mutta vain noin prosentin desimaalin verran.

6 Ärsykkeen tälle artikkelille antoivat kokemukseni taitotason kohottamista käsittelevässä seminaarissa Bambergissa, http://www.iaq. uni-due.de/iwplms/about.php. Siellä minun koulutusoptimismilleni vähän hymyiltiin, monista maista kun raportoitiin päinvastaisesta kehityksestä, sekä koulutuksen että sen vaikuttavuuden vähenemisestä.

7 Mincer $(1989,1994)$ oli vakuuttunut siitä, että jos elinkaaren aikana hankitusta aikuiskoulutuksesta olisi kelvollista tietoa ollut, moni kilpaileva teoria olisi jäänyt syntymättä. Toki puute työuran aikaisista koulutustiedoista tutkimusta edelleen vaivaa, ja siksi valtaosa alan kirjallisuudesta perustuu aikuiskoulutuksen lyhyen aikavälin vaikutusten arviointiin. Se on ongelmallista, sillä elinikäisen oppimisen vaikutusten arviointiin sopii parhaiten elinkaarimalli

8 Ensin tarkoitukseni oli ottaa perusjoukoksi työlliset, so. palkansaajat ja yrittäjät, joista valtaosa on nykyään yksinyrittäjiä, ja työmarkkina-asemaltaan palkansaajan kaltaisia. Vuoden 2006 aineistossa yrittäjätulot olivat kuitenkin epäuskottavan pienet muihin tilastolähteisiin verrattuna. Palaan tähän asiaan myöhemmin

9 Menetelmä on karkea, mutta vastaa laadullisesti koulutusasteiden muuntamista koulutusvuoksiksi: kaikkien koulutusasteen X palkansaajille koulutusvuosiksi merkitään $Y$ vuotta. Näin on alan kirjallisuudessa tehty jo noin 40 vuoden ajan. Tässä puheena olevan jatkuvan aikuiskoulutusmuuttujan johtamisen olen seikkaperäisesti esittänyt väitöskirjassani (Laukkanen 2010, 49-50).

10 Mahdollisten epälineaarisuuksien selventämiseksi estimoin mallin myös siten, että se sisälsi laskennallisten aikuiskoulutuskurssien neliön. Tämän termin etumerkki on kaikille vuosille tilastollisesti ei-merkitsevä.

Artikkeli saapui toimitukseen 10.8.2011. Se hyväksyttiin julkaistavaksi toimituskunnan kokouksessa 23.1.2012.

Erkki Laukkanen sai tämän artikkelin kirjoittamiseen Työsuojelurahaston stipendin. 